\title{
Penerapan Model Pembelajaran Berbasis Masalah Berbantu Media Gambar Guna Meningkatkan Hasil Belajar
}

\author{
Yunita Dewi ${ }^{*}$, Elvira Hosein Radia ${ }^{2}$ \\ 1,2 Program Studi Pendidikan Guru Sekolah Dasar, FKIP Universitas Kristen Satya Wacana Salatiga
}

\section{A R T I C L E I N F O}

Article history:

Received 19 February 2019

Received in revised form

30 March 2019

Accepted 10April 2019

Available online 20 May 2019

Kata Kunci:

Hasil belajar, Tematik

Model pembelajaran

berbasis masalah.

Keywords:

Learning outcomes,

Thematic, Problem based

learning models.

\begin{abstract}
A B S T R A K
Tujuan peneltian ini untuk mengetahui adanya peningkatan adanya peningkatan hasil belajara tema 6 subtema 2 pembelajaran 1 dan 2 siswa kelas IV SD N Mangunsari 02 Salatiga menggunakan model pembelajaran berbasiskan masalah (PBL). Jenis penelitian ini adalah Penelitian Tindakan Kelas (PTK). hasil penelitian yang diperoleh dari siswa kelas IV SD N Mangunsari 02 Salatiga yang berjumlah 21 siswa adalah (1) pada pembelajaran pra siklus hasil belajar siswa selama mengikuti pembelajaran terdapat 14 siswa yang tidak tuntas dengan presentase $66,67 \%$ dan yang sudah tuntas sebanyak 7 dengan presentase 33,33 siswa yang terdapat pada pembelajaran pra siklus. (2) pada pembelajaran menggunakan model pembelajaran berbasis masalah (PBL) berbantu media gambar pada siklus I siswa yang tuntas menjadi 12 siswa dengan persentase $57,15 \%$ dan yang tidak tuntas terdapat 9 siswa dengan presentase $42,85 \%$. (3) hasil penelitian pada siklus II siswa yang tuntas menjadi 17 siswa dengan presentase $80,95 \%$ dan yang tidak tuntas terdapat 4 siswa dengan presentase $19.05 \%$. hasil belajar tema 6 subtema 2 pembelajaran 1 dan 2 mengalami kenaikan yang signifikan bagi siswa kelas 4 SD N Magunsari 02 Salatiga, siswa terlihat aktif,ceria, menyenenangkan dan juga antusias dalam proses pembelajaran.
\end{abstract}

A B S T RACT

The purpose of this research is to find out an increase in the learning outcomes of the 6 subthemes 2 of learning 1 and 2 fourth grade students of SD N Mangunsari 02 Salatiga using a problembased learning model (PBL). This type of research is Class Action Research (CAR). the results of research obtained from fourth grade students of SD N Mangunsari 02 Salatiga which amounted to 21 students were (1) in the pre-cycle learning outcomes of student learning during the learning there were 14 students who did not complete with a percentage of $66.67 \%$ and 7 completed with percentage of 33.33 students found in pre-cycle learning. (2) in learning using a problem-based learning model $(P B L)$ assisted by image media in the first cycle of students who completed 12 students with a percentage of $57.15 \%$ and those that did not complete there were 9 students with a percentage of $42.85 \%$. (3) the results of the study in the second cycle of students who finished into 17 students with a percentage of $80.95 \%$ and those that did not complete there were 4 students with a percentage of $19.05 \%$. learning outcomes theme 6 sub-theme 2 learning 1 and 2 experienced a significant increase for 4th grade students of SD N Magunsari 02 Salatiga, students seemed active, cheerful, pleasant and also enthusiastic in the learning process. 


\section{Pendahuluan}

Kurikulum 2013 proses pembelajaran diarahkan pada penyajian materi secara terpadu untuk mencapai semua aspek kompetensi secara utuh untuk menekankan pada pembentukan sikap dan karakter peserta didik. Menurut Trianto (2012: 5) salah satu prinsip kurikulum yang memberikan atribut secara penuh kepada instansi sekolah untuk merancang dan merencanakan sendiri pembelajaran sesuai dengan kondisi dan tingkat kemampuan sekolah. Pada pembelajaran kurikulum 2013 dilaksanakan dengan menggunakan pendekatan imliah (scientific), tematik terpadu. Sehingga sekolah mempunyai wewenang untuk melakukan pembelajaran yang sesuai dengan lingkungan sekolah. Hal tersebut sejalan dengan pendapat Trianto (2010:70), bahwa pembelajaran tematik adalah pembelajaran terpadu yang menggunakan tema untuk mengaitkan beberapa mata pelajaran sehingga dapat memberikan pengalaman belajar yang bermakna kepada siswa.

Pembelajaran pada siswa tidak hanya bersifat teoritis namun, dapat di berikan melalui pengalaman belajar yang berkaitan dengan dunia nyata. Salah satu pembelajaran yang bisa diterapkan terhadap siswa adalah media gambar, dengan media gambar siswa jadi lebih tertarik terhadap materi yang akan disajikan dengan begitu siswa menjadi antusias terhadap materi. Menurut Sanjaya (2011:214) menyebutkan bahwa gambar adalah salah satu media grafis yang paling umum dipergunakan dalam proses pembelajaran, hal ini dikarenakan gambar memiliki kelebihan sifatnya kongret, lebih realistis, dan dapat memperjelas suatu masalah dalam bidang apa saja. Dengan media gambar siswa diharapkan mampu meningkatkan hasil belajar tema 6 subtema 2 pembelajaran 1 dan 2 dengan model pembelajaran berbasiskan masalah (PBL). Hasil belajar berkaitan dengan kemampuan yang di miliki siswa dalam menyerap dan memahami materi yang telah di ajarkan oleh guru. Hasil belajar menurut Susanto (2013:5) adalah perubahan-perubahan yang terjadi pada siswa, baik secara aspek kognitif, afektif dan psikomotor setelah melalui kegiatan belajar. Hasil belajar menurut Sudjana (2010:22) adalah kemampuan yang dimiliki siswa setelah siswa menerima pengalaman belajarnya. Pengalaman belajar ini akan menghasilkan kemampuan yang menurut Horwart Kinggsley dalam buku Nana Sudjana,(2010:22) dibedakan menjadi tiga macam kemampuan (hasil belajar) yaitu: (1) Ketrampilan dan kebiasaan, (2) Pengetahuan dan pengarahan, (3) Sikap dan cita-cita. Hasil belajar akan menjadi acuan bagi guru untuk mengetahui ketercapaian proses pembelajaran yaitu memperbaiki proses pembelajaran atau meningkatkan proses pembelajaran. Hasil belajar yang diperoleh antara siswa satu dengan siswa lain tidak sama, hal ini di pegaruhi oleh kemampuan akademik yang berbeda dan pengalaman yang berbeda.

Namun pada kenyataan yang terjadi hasil belajar siswa kelas IV SD N Mangunsari 02 Salatiga belum dalam melibatkan siswa secara aktif untuk berusaha membangun dan menemukan pengetahuan sendiri. Dalam penggunakan model guru menggunakan model tanya jawab dan juga penugasan pada setiap materi namun dalam penggunakan media guru belum menggunakan media secara maksimal hal itu dibuktikan dengan guru belum memanfaatkan adanya berbagai media yang terdapat di Perpustakaan dan alam sekitar yang juga dapat dijadikan sebagai materi saat mengajar hal ini dapat menyebabkan proses pembelajaran menjadi sedikit terhambat, sehingga mempengaruhi hasil belajar siswa. Untuk menyelesaikan masalah tersebut perlu adanya model pembelajaran yang cocok untuk meningkatkan hasil belajar salah satunya yaitu model pembelajaran berbasiskan masalah (PBL), denga model pembelajaran berbasis masalah siswa dibiasakan untuk ingin tahu, dan membiasakan siswa untuk berpikir kritis dan kreatif dalam memecahkan suatu permasalahan baik berkaitan dengan pembelajaran maupun dengan kehidupan-sehari-hari.

Problem Based Learning atau di singkat dengan PBL merupakan satu bentuk metode pembelajaran inovatif yang berpusat pada siswa dan di tempatkan pada masalah kongret yang ada pada sekitar mereka Menurut Henny Dewi (2018:65). Pendapat tersebut sejalan dengan pendapat Wardani (2010:02) model pembelajaan berbasis masalah dapat menyajikan masalah autentik dan bermakna sehingga mahasiswa dapat melakukan penyeledikann dan menemukan sendiri. Model Pembelajaran Berbasis Masalah (PBL) memberi pengalaman yang beragam pada siswa seperti kerja sama dan interkasi dalam kelompok, di samping pengalaman belajar yang berhubungan dengan masalah seperti membuat hipotesis, merancang percobaan, melakukan penyelidikan, mengumpulkan data, mengiterprestasikan data, membuat kesimpulan, mempresentasikan, berdiskusi dan membuat laporan. Keadaan tersebut menunjukan bahwa Model Pembelajaran Berbasis Masalah (PBL) dapat memberi pengalaman yang kaya kepada siswa. Sehingga dengan di terapkan Model Pembelajaran Berbasis Masalah (PBL) ini siswa lebih aktif dalam pembelajaran dan antusisas terhadap pembelajaran. Sehingga penggunaan Model Pembelajaran Berbasis Masalah (PBL) dapat membangun suasana belajar yang menarik siswa dan memancing siswa untuk aktif dan ingin tahu. Menurut Amir (2009:22) karakteristik yang terdapat dalam Model Pembelajaran Berbasis Masalah (PBL) adalah (1) Masalah digunakan sebagai awal pembelajaran (2) Biasanya masalah yang digunakan merupakan masalah dalam dunia nyata yang disajikan secara 
mengambang (ill-structured) (3) masalah biasanya majemuk (multiple perspektif). (4) Masalah membuat pembelajaran tertantang untuk mendapat pembelajaran diranah pembelajaran yangg baru. (5) Sangat mengutamakan belajar mandiri (self direct learning). (6) Memanfaatkan sumber pengetahuan yang bervariasi tidak dari satu sumber saja. (7) Pembelajaran klaboratif, komunikatif, dan kooperatif. Pembelajar bekerja dalam kelompok. Berinteraksi, saling mengajarkan (peer teaching), dan melakukan presentasi. Adapula tahap-tahap Model Pembelajaran Berbasis Masalah (PBL) Menurut Arend (dalam Koeswanti , 2018:75) yaitu:

Tabel 1. Tahap-pelaksanaan Problem Based Learning

\begin{tabular}{|c|c|c|}
\hline Fase & Tahap-tahap & Perilaku Guru \\
\hline 1. & Penyajian masalah & $\begin{array}{l}\text { Siswa mendapatkan penyajian masalah dalam bentuk } \\
\text { pertanyaan yang diberikan guru. }\end{array}$ \\
\hline 2. & Pengorganisasian siswa & $\begin{array}{l}\text { Siswa secara aktif melakukan perencanaan penyelidikan } \\
\text { bersama kelompok dengan bimbingan guru }\end{array}$ \\
\hline 3. & Penyelidikan kelompok & $\begin{array}{l}\text { Siswa melakukan kegiatan penyelidikan } \\
\text { mengumpulkan data-data yang dibutuhkan } \\
\text { menyelesaikan masalah. }\end{array}$ \\
\hline 4. & $\begin{array}{l}\text { Pengembangan dan penyajian } \\
\text { hasil }\end{array}$ & $\begin{array}{l}\text { Setiap perwakilan kelompok menyampaikan hasil } \\
\text { penyelidikan berdasarkan hasil analisis kelompok. }\end{array}$ \\
\hline 5. & $\begin{array}{l}\text { Pengevaluasian } \\
\text { penyelidikan }\end{array}$ & $\begin{array}{l}\text { Siswa membuat kesimpulan dan rangkaian dari hasil } \\
\text { penyelidikan yang telah mereka lakukan dengan } \\
\text { bimbingan guru. }\end{array}$ \\
\hline
\end{tabular}

Fenomena yang terjadi saat ini di SD N Mangunsari 02 Salatiga pada kelas 4 dalam pembelajaran saat ini belum sesuai dengan yang diharapkan. Untuk mengatasi masalah yang dialami siswa kelas IV SD N Mangunsari 02 Salatiga maka diadakan penelitian tindakan kelas (PTK) dengan judul "penerapan model pembelajaran berbasis masalah (PBL) berbantu media gambar untuk meningkatkan hasil belajar tema 6 kelas IV SD N Mangunsari 02 Salatiga" suatu penelitian tentu mempunyai permasalahan yang harus di atasi dan dipecahkan. Dalam penelitian ini dapat di rumuskan "apakah penggunakna model pembelajaran berbasiskan masalah (PBL) dapat meningkatkan hasil belajar tema 6 pada kelas IV SD N Mangunsari 02 Salatiga? dan Bagaimana penggunaan model pembelajaran berbasiskan masalah (PBL) dapat meningkatkan hasil belajar tema 6 siswa kelas IV SD N Mangunsari 02 Salatiga?"Penelitian ini bertujuan (1) untuk meningkatkan hasil belajar Tema 6 siswa kelas IV SD N Mangunsari 02 Salatiga (2) Menerapkan model pembelajaran Berbasis Masalah (PBL) agar dapat meningkatkan hasil belajar Tema 6 siswa kelas IV SD N Mangunsari 02 Salatiga.

\section{Metode}

Penelitian ini dilaksanakan di SD N Mangunsari 02 Salatiga. Sebagai subjek penelitian adalah siswa kelas IV SD N Mangunsari 02 Salatiga dengan jumlah siswa 21 siswa yang terdiri dari 6 siswa prempuan dan 15 siswa laki-laki. Sebagai ojek penelitian tema 6 subtema 2 pembelajaran 1 dan 2 . Penelitian dilaksanakan pada bulan Januari-Maret 2019 semester genap tahun ajaran 2018/2019

Sesuai dengan jenis penelitian yang dipilih yaitu penelitian tindakan kelas (PTK), maka penelitian ini menggunakan model penelitian dari C.Kemmis dan Mc.Taggart,R yang berbentuk spiral yaitu meliputi perencanaan, pelaksanaan,observasi dan refleksi. Sebelum masuk di siklus I dilakukan tindakan pendahuluan yang berupa indentifikasi permasalahan yang terjadi

Pelaksaan penelitian tema 6 subtema 2 pembelajaran 1 dan 2 dilaksanakan didalam kelas IV SD N Mangunsari 02 Salatiga. Di dalam peneliti ini ada 3 kali pertemuan yang terdiri dari pertemuan 1 dan 2 merupakan penyampaian materi sedangkan yang pertemuan ke 3 di gunakan untuk melakukan evaluasi, sama halnya juga dengan siklus II yang tediri dari 3 kali pertemuan

Adapun data yang di ambil dalam proses penelitian ini dengan cara menggunakan lembar observasi. Teknik pengumpulan data yang digunakan untuk memperoleh data dlam penelitian ini adalah tes dan juga observasi.tes di gunakan untuk mengetahui peningkatan hasil belajar siswa selama kegaiatan pembelajaran tema 6 subtema 2 pembelajaran 1 dan 2 terdapat 20 butir soal yang terdapat dalam tes. Sebelum di instrument di ujikan terlebih dahuli dianalisis uji validitas dan reliabilitas mengunkan SPSS Inc PASW Statistics 18.

Kegiatan ini digunakan untuk pengumpulan data sebagai bahan refeksi dan juga analisis. Observasi dilakukan oleh peneliti. Intrumen pengumpula data dengan metode tes dan lembar observasi 
dan juga dokumentasi di gunakan dalam penelitian untuk mengethaui pencapaian tujuan dalam rencana yang sudah di buat dalam Rencana Pelaksanaan Pembejajaran yang melipti aspek kognitif,afektif dan psikomotorik. Untuk ketuntasan belajar Yaitu seorang siswa telah tuntas belajar apabila telaj mencapai skor diatas 68,00 .

\section{Hasil dan Pembahasan}

Penelitian ini terdapat 3tahapan dalam yaitu ada pra siklus, siklus 1 dan siklus 2, pra siklus merupakan kondisi awal sebelum dilaukannya tindkan kelas atau tindakan penelitian. Siklus 1 dan 2 adalah pelaksanna tindakan kelas dengan menggunkan model pembelajara berbasis masalah (PBL). Berdasarkan pengamatan dan setelah melakukan analisa terhadap data yang diperoleh dari pra siklus, siklus I dan siklus II maka dapat disimpulkan bahwa dengan menerapkan pembelajaran berbasis masalah (PBL) pada tema 6 subtema 2 pembelajaran 1 dan 2 menunjukan peningkatan hasil belajar pada siswa kelas IV SD N Mangunsari 02 Salatiga

Pra siklus

Ketuntasan hasil belajar siswa sebelum dilakukan tindakan diketahui bahwa siswa yang memiliki nilai di bawah KKM $(68,00)$ sebanyak 14 atau 66,67\%, sedangkan yang sudah mencapai ketuntasan KKM $(68,00)$ sebanyak 7 siswa dengan presentase 33,33\%. Dengan nilai rata-rata 68,4 dan nilai yang tertinggi 75 sedangkan nilai yang terrendah 65 dan dengan jumlah nilai 1438 dari jumlah 21 siswa. Hasil belajar yang yang rendah karena proses pembelajaran memiliki beberapa hambatan saat proses pembelajaran berlangsung seperti halnya ini disebabkan kurangnya partisipasi siswa pada saat kegiatan pembelajaran yang berlangsung,siswa sibuk sendiri, siswa bermain dengan teman sebangku, hal tersebut membawa dampak dari hasil belajar yang kurang baik bagi siswa yang tidak memperhatikan pembelajaran. Oleh karena itu perlu diadakan penelitian tindakan kelas dengan menerapakan model pembelajaran berbasiskan masalah (PBL)

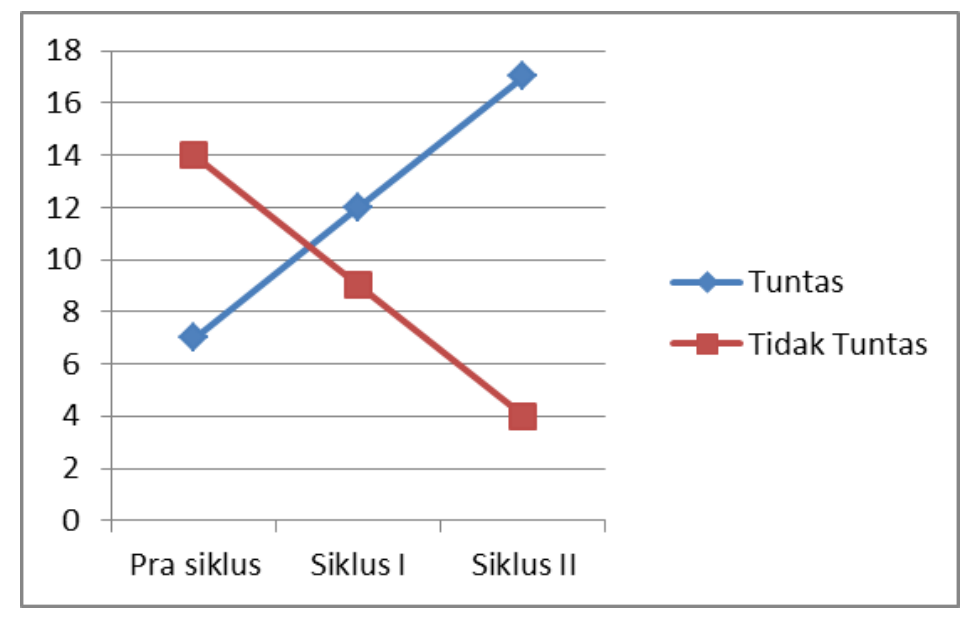

Gambar 1. Grafik Perbandingan Ketuntasan Hasil Belajar Tema 6 subtema 2 pembelajaran 1 dan 2 Tiap Siklus Siklus I

Siklus I

Dari grafik diatas diperoleh ketuntasan pada siklus I yang tuntas ada 17 siswa dengan persentase $80,95 \%$ dan yang tidak tuntas terdapat 4 siswa dengan persentase 19,05\% dengan nilai rata-rata 68,8 dan jumlah nilai keseluruhan 1445 dengan jumlah nilai tertinggi 95 dan jumlah nilai terrendah 40 dari 21 siswa. Berdasarkan data yang telah diketahui hasil belajar menunjukan bahwa ada peningkatan dari data sebelum tindakan siklus I

Pada siklus I pengamatan terhadap aktivitas guru mencapai skor 75,83\% . Dengan demikian, pengamatan aktivitas guru dalam penerapan model pembelajaran berbasis masalah (PBL) mencapai indikator keberhasilan, yaitu baik. sedangkan aktivitas belajar siswa menunjukan skor 75,83\% mencapai kategori baik.

Berdasarkan hasil penelitian didapatkan masih ada kekurangan yang diperoleh pada siklus pertama, maka peneliti sebagai sumber belajar melakukan perbaikan pada siklus kedua, perbaikan perbaikan tersebut antara lain (1) siswa diharapkan menikmati proses model pembelajaran berbasis masalah (PBL) pada siklus pertama (2) pengaturan kelas agar suasana kondusif dalam belajar (3) 
ketegasan dalam mengatur siswa yang susah diatur dalam proses pembelajaran. Dalam lembar pengamatan guru saat proses pembelelajaran maka dari kekurangan terebut harus diperbaiki dalam siklus 2

Siklus II

Pada siklus II pengamatan terhadap aktivitas guru dalam menerapkan model pembelajaran berbasis masalah (PBL) mencapai skor 91,66\%. Dengan demikian, pengamatan aktivitas guru dalam menerapkan model pembelajaran berbasis masalah (PBL) mencapai kreteria indikator sangat baik. Sedangkan aktivitas siswa menunjukan peningkatan dari aktivitas belajar dari siklus sebelumnya. Aktivitas siswa mencapai jumlah skor 97,5\% dengan kreteria indikator sangat baik. Dengan demikian aktivitas belajar siswa pada siklus II mencapai indikator keberhasilan yang diharapkan peneliti

Hasil penelitian yang dilakukan pada siklus II di peroleh ketuntasan belajar pada tema 6 subtema 2 pembelajaran 1 dan 2 terdapat ketuntasan hasil belajar siswa yang telah tuntas nilai di atas KKM $(68,00)$ ada 17 siswa dengan persentase 80,95\% dan yang hasil belajar nilai di bawah KKM $(68,00)$ terdapat ada 4 siswa dengan persentase 19,05\% dengan njumlah keseluruhan nilai 1545 dan nilai tertinggi 95 serta terdapat nilai terrendah 50 dan memiliki rata-rata nilai 73,5 dari 21 siswa kelas IV SD N Mangunsari 02 Salatiga

\section{Simpulan}

Berdasarkan hasil penelitian dan pembahasan maka dapat disimpulkan dengan menggunakan model pembelajaran berbasis masalah (PBL) berbantu media gambar dengan tahap pembelajaran penyajian masalah, pengorganisasian siswa, penyelidikan kelompok dan pengembangan dan penyajian hasil dan pengevaluasian hasil penyelidikan dapat meningkatkan hasil belajar siswa kelas IV SD N Mangunsari 02 Salatiga dengan hasil belajar di atas KKM $(68,00)$ dalam muatan pembelajaran IPA, Bahasa Indonesia dan SBdP pada pokok bahsan daur hidup hewan, tarian tradisional dan unsur dalam puisi. Siswa antusias dalam pembelajaran dan menyenangkan dalam proses pembelajaran.

\section{Daftar Rujukan}

Amir,M Taufiq.2009.Inovasi Pendidikan melalui Problem Based Learning: Bagaimana Pendidikan Memberdayakan Pembelajaran di era pengetahuan.Jakarta: Kencana

Koeswanti, Henny Dewi.2018. Eksperimen Model Kooperatif Learning dalam pembelajaran Ketrampilan Menulis Karya Ilmiah Mahasiswa Ditinjau dari Kemampuan Berpikir Logis. Salatiga: Satya Wacana University Press.

Nanik Sulistya Wardani,d.(2012).ASESMEN PEMBELAJARAN SD Bahan Belajar Mandiri.Salatiga:Widya Sari.

Sanjaya, Wina. 2011 . Strategi Pembelajaran Berorientasi Standar Proses Pendidikan..Jakarta:Kencana

Sudjana, Nana.2010. Dasar-dasar Proses Belajar Mengajar. Bandung: Remaja Rosdakarya

Trianto. 2010. Model PembelajaranTerpadu.Jakarta:2013.Model Pembelajaran Terpadu Konsep,Stategis dan Implementasi dalam Kurikulum Tinggkat Satuan Pendidikan(KTSP).Jakarta:Bumi Aksara

Trianto. 2010. Mengembangkan Model PembelajaranTematik. Jakarta: PrestasiBelajar.

Susanto, Ahmad. 2013. Teori Belajar\&Pembelajaran di SekolahDasar. Jakarta: Prenadamedia Group.

Agustini, Putu Putri, dkk. 2016. “Penerapan Model Pembelajaran Berbasis Masalah Berbantuan Media Audio Visual untuk Meningkatkan Hasil Belajar Keterampilan Menyimak Tema Sejarah Peradaban Indonesia pada Siswa Kelas V SDN 8 Sumerta". eJournal PGSD Universitas Pendidikan Ganesha, Vol. 4, No. 1 (hlm 1-10). 
Wardhani, G. S., \& Wasitohadi, W. 2018. "Penerapan Model Pembelajaran Berbasis Masalah Berbantuan Media Gambar untuk Meningkatkan Aktivitas dan Hasil Belajar IPA Siswa Kelas 4 SD”. Jurnal Handayani PGSD FIP UNIMED, Vol. 8, No. 1 (hlm 120-125).

Aryani, A., dkk. 2018. "Penerapan Model Pembelajaran Berbasis Masalah untuk Meningkatkan Hasil Belajar IPA siswa Kelas III SDN 036 Sintong". Jurnal Online Mahasiswa (JOM) Bidang Keguruan dan Ilmu Pendidikan, 5(1), 1-10.

Siswantara, I., \& Agus, G. 2013. Penerapan Model Problem Based Learning (PBL) untuk Meningkatkan Aktivitas dan Hasil Belajar IPA Siswa kelas IV SD Negeri 8 Kesiman. Jurnal PGSD. Universitas Pendidikan Ganesha Singaraja. 